\title{
ゲル化時間の短い急結・瞬結性薬液の砂質地盤における 注入固結形態とその支配条件 \\ SOLIDIFIED SHAPES BY SHORT GEL TIME GROUTS IN SANDY GROUND AND THE GOVERNING CONDITION
}

\author{
森麟*・田村昌仁**・原口賢一*** \\ By Akira MORI, Masahito TAMURA and Ken-ichi HARAGUCHI
}

\begin{abstract}
In order to elucidate the mechanism of permeation by short gel time grouts, we investigated the effects of injection pressure $P^{\prime}$, injection rate $q$, injection time $t$, and gel time $G t$ on the solidified shapes. Through a lot of injection tests using the large injection apparatus, we obtained the following conclusions. 1) Permeation without fracturing is possible as long as $P^{\prime}$ is increasing during injection. 2) If the permeability of sand is large enough, the succesive grout can permeat spherically by perforation in the pore gel at the solidified part.
\end{abstract}

Keywords : grouting, short get time grout, sandy soil, solidified shape

\section{1. まえがき}

砂質地盤を対象とする薬液注入では, 注入時間よりも ゲル化時間が長い緩結性の薬液を用いて浸透注入を目指 すことが基本であるが，工法の簡単なゲル化時間の短い 急結性・瞬結性の薬液が使用される場合も少なくない. 緩結性薬液についての注入形態を支配する条件について は文献 1) で明らかにしたが，急結・瞬結性薬液につい ては不明な部分が多く, 土質条件や薬液ゲル化時間に応 じた注入方法の確立が急務とされている21,31.

ゲル化時間が注入時間よりかなり短い瞬結性, 急結性 薬液の場合は, 先行薬液による浸透部分が薬液のゲル化 により固結すると後続薬液はその部分を突き破って割裂

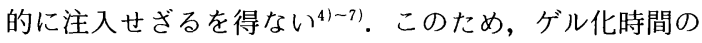
短い薬液による注入状況は, 先行薬液を絶えず遠方に押 し出していく緩結性薬液の場合と大きく異なると考えら れるが, 薬液の浸透メカニズムや注入が可能な条件につ いてはほとんど明らかでない。

* 正会員 工博 早稲田大学教授 土木工学科 （１60 新宿区大久保 3-4-1)

** 正会員 工博 建設省建築研究所 第三研究部 ( テ305 つくば市立原 1)

*** 正会員 工修 大成建設 (株) (元・早稲田大学大学院生) ( ₹160-91 新宿区西新宿 1-25-1)
本研究の目的は, 急結・瞬結性薬液における注入のあ り方を明確にすることにあり, 大型土槽を用いた注入実 験により, 注入固結形態の支配条件や浸透注入可能限界 を調査研究したものである.

\section{2. 実験方法および試料}

写真一1 および図一1には, 実験装置の概要を示す. 実験土槽は, 内径 $80 \mathrm{~cm}$, 高さ $100 \mathrm{~cm}$ の鋼製多孔質円 筒で側面からの排水が可能なように $3 \mathrm{~mm}$ の孔が多数あ いており, 内壁には $0.1 \mathrm{~mm}$ の金属メッシュが全周に張 り付けてある. その内円筒の外側を内径 $100 \mathrm{~cm}$, 高さ $100 \mathrm{~cm}$ のアクリル円筒で囲み, この中を水で満たすこ とができる．試料砂は内円筒内にベルトコンベアを用い て自由落下させ水締めした。このようにして作製した土 槽の上表面にゴム風船を入れ内円筒の上盤をボルトで固 定し, ゴム風船を水で満たしコンプレッサーで加圧して 試料に上載圧を与える.上載圧 $\sigma_{V}$ は, すべて $1 \mathrm{kgf} / \mathrm{cm}^{2}$ とした.

注入圧 $P^{\prime}$ は，注入管下端に取り付けた圧力計による 実測值から地下水圧と管内抵抗の值を減じたものとし た. 管内抵抗は注入実験の場合と等しい注入速度で薬液 を空の土槽内に放出した場合の圧力計の読みである。ま た, 注入中の割裂状況を調べるため加圧用ゴム風船内の 


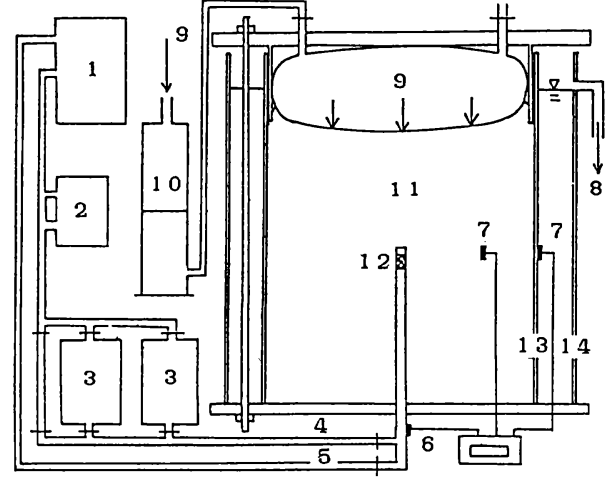

1 : 定速ボンフ 2 : 電磁流量計 3 : 着色B夜用タンク $4:$ 液 $5:$ : 液 6 : 注入压 $7:$ 土圧 8 : 越流量 9 : 上载压 10 : 水タンク 11 : 砂試料 12 : 注入管 13 : 銅製内筒 $(\phi 800 \mathrm{~mm}) \quad 14$ : 外成筒 $(\phi 1000 \mathrm{~mm})$

図一1 注入実験土槽

(供試体直径 $800 \mathrm{~mm}$ ，高さ $800 \mathrm{~mm}$ )

\section{表一1 砂の種類}

\begin{tabular}{|c|c|c|c|c|}
\hline 試料 & 摘 & $\begin{array}{l}\text { 間隙比 } \\
\mathbf{e}\end{array}$ & $\begin{array}{c}\text { 透水係数 k } \mathrm{k} \\
(\mathrm{cm} / \mathrm{sec})\end{array}$ & $\underset{\phi d}{\phi_{d}}$ \\
\hline A & 市肘ヶイ砂 3 号 & 1.09 & 1. $1 \times 10^{\circ}$ & 34.7 \\
\hline B & 市販ヶイ砂 5 号 & 0.88 & 1. $3 \times 10^{-1}$ & 34.3 \\
\hline C & 市眅ヶイ砂 6 号 & 1.00 & 5. $3 \times 10^{-2}$ & 34.8 \\
\hline D & $B: E=5: 5$ & 1.00 & 2. $0 \times 10^{-2}$ & 33.4 \\
\hline $\mathrm{E}$ & 市販ヶイ砂 7 号 & 1.00 & 5. $1 \times 10^{-3}$ & 38.1 \\
\hline F & 市肘ヶイ砂 8 号 & 1.00 & 1. $6 \times 10^{-3}$ & 38.4 \\
\hline G & $E: I=9: 1$ & 1.00 & 2. $4 \times 10^{-3}$ & 36.1 \\
\hline $\mathrm{H}$ & $E: I=3: 1$ & 1.00 & 7. $8 \times 10^{-4}$ & 37.6 \\
\hline
\end{tabular}

試料Dは, 試料 $\mathrm{B}$ と試料 $\mathrm{E}$ を 5 ：5 の重量比で混合したもの 試料 $G, H$ は, 試料 $\mathrm{E}$ と試料 I（木節粘土）を $9: 1,3: 1$ の重量比で混合したもの

水の出入りを調べて供試体の体積変化を求めた．水の出 入りは，図一1の水タンクの水位差で読み取った.

表一1には, 試料の透水係数と摩擦角を示す。また, 図一2には試料の粒度分布曲線を示す，使用した砂は主 に市販のケイ砂を用いたが，透水係数を変えるため木節 粘土との混合土も用いた. 透水係数 $k$ は定水位試験法 により，摩擦角 $\phi_{d}$ は三軸排水試験により求めた。

薬液はゲル化時間の異なる 3 種類（瞬結性, 急結性, 緩結性）を使用することにし，表一2には，薬液の配合 とゲル化時間 $G t$ を示す. ゲル化時間 $G t$ は, 注入実験 に先立って実際に使用する注入管（管の先端で薬液の混 合が可能な二重管式）と同一なものを使用して求めるこ とにし, 注入管より流出した薬液がゲル化するまでの時 間とした。また，注入ポンプと注入管までの間にウォー ターブルー（青色）およびローダミン（赤色）で着色し た B液を満たした 2 つのタンク（図一1 参照）を設置し ており,バルブを切り替えることにより着色 B 液を時間 差注入して薬液の浸透状況を調查した.

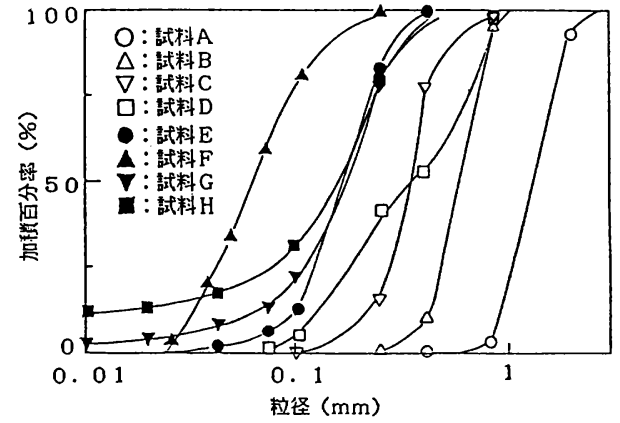

図一2 粒度分布曲線

表一2 薬液の種類

\begin{tabular}{|c|c|c|c|}
\hline \multirow[t]{2}{*}{ 種 類 } & \multicolumn{2}{|c|}{ 配 合 } & \multirow{2}{*}{$\begin{array}{l}\text { ゲル化時間 } \\
\text { G } t\end{array}$} \\
\hline & A夜 $500 \mathrm{cc}$ & $\mathrm{B}$ 液 $500 \mathrm{cc}$ & \\
\hline 瞬結性 & $\begin{array}{r}3 \text { 号水ガラス } \\
250 \mathrm{cc} \\
\text { 水 } 250 \mathrm{cc}\end{array}$ & 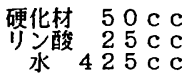 & $\begin{array}{c}5 \sim 10 \\
\text { (秒) }\end{array}$ \\
\hline 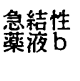 & $\begin{array}{r}3 \text { 号水ガラス } \\
250 \text { c c } \\
\text { 水 } 250 \text { c c }\end{array}$ & 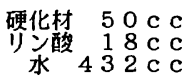 & 50 (秒) 70 \\
\hline 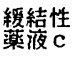 & $\begin{array}{r}3 \text { 号水ガラス } \\
250 \mathrm{c} \\
25 \\
\text { 水 } 250 \mathrm{cc}\end{array}$ & 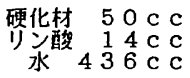 & $20 \underset{(\text { 分) }}{30}$ \\
\hline
\end{tabular}

3 号水ガラス: $\mathrm{Na}_{2} \mathrm{O} \cdot 3 \mathrm{SiO}_{2} \cdot \mathrm{aq}, \quad$ リン酸 $: \mathrm{H}_{3} \mathrm{PO}_{4}(75 \%)$

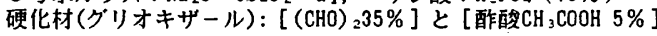

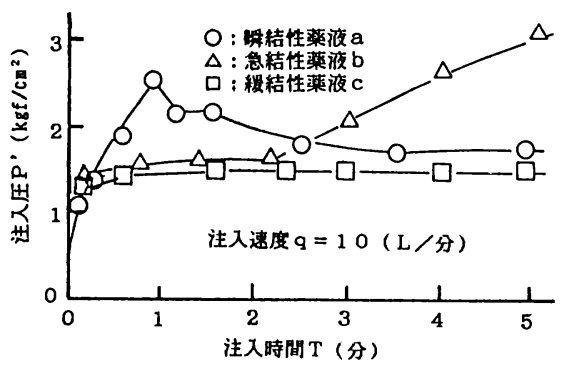

図一3 試料Eの注入压 $\boldsymbol{P}^{\prime}$ と注入時間 $\boldsymbol{T}$ の関係

\section{3. ゲル化時間の短い薬液の注入圧}

\section{（1）注入圧に及ぼすゲル化時間の影響}

薬液注入における注入管理は注入圧で行われることが 多いが, 注入圧に及ぼす薬液ゲル化時間, 注入速度, 砂 の透水性の影響については現時点においてもほとんだ不 明で注入圧の意味するところが明らかでない．この章で は，この注入圧の特徵について調査した。

図一3 は, 試料E (ケイ砂 7 号) に, 全注入量 $Q=50$ $(\mathrm{L})$, 注入速度 $q=10$ ( $\mathrm{L} /$ 分), 全注入時間 $t=5$ (分間) で薬液 $\mathrm{a}, \mathrm{b}, \mathrm{c}$ を注入した場合の注入圧 $P^{\prime}$ と注入時間 $T$ の関係を示す. 図一 4 は供試体の体積膨張量 $V$ と注 入時間 $T$ の関係である.

緩結性薬液 c では, 注入圧は注入中ほとんど変化せず 


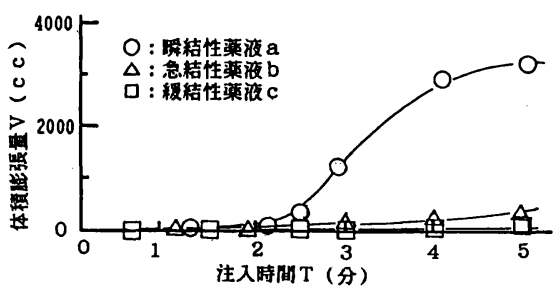

图一4 注入過程における試料 Eの体積变化

一定值を示している。一方, 注入中に薬液がゲル化する 薬液 $\mathrm{a}, \mathrm{b}$ では注入圧の増加が認められるが，これは先 行薬液がゲル化して透水性がより低下した部分を後続薬 液が突き破っているためと考えられる．瞬結性薬液ａで は, 注入直後から注入圧が増加しているがその後減少し て一定值となる．急結性薬液 b では，ゲル化するまでは 緩結性薬液 $\mathrm{a}$ とほぼ等しい注入圧であり, その後ゲル化 とともに注入圧は増加している. 写真一2には，それぞ れの固結形状を示しているが，瞬結性薬液 a では垂直な 厚板状, 薬夜 $\mathrm{c}$ では完全な球形状, 薬液 $\mathrm{b}$ はその中間の 形状であることがわかる.

注入中の体積膨張量の大部分は，割裂注入が発生した 場合に制裂脈が土を押し拡げた量に相当するので，膨張 量が著しく大きい薬液 a の場合は最も大きな脈が発生し ていることになる，薬液 c では体積膨張が認められず, 固結形状が球状で浸透注入が得られた結果と一致する.

図一 5 は, 試料 $\mathrm{E} よ り$ 透水係数が著しく大きい試料 $\mathrm{A}$ (ケイ砂 3 号) に対して, $Q=50(\mathrm{~L}), q=5$ (L/分), $t=10$ (分間) の注入における注入圧 $P^{\prime}$ 之注入時間 $T$ の関係を示す．写真一 3 には, 瞬結性薬液 $\mathrm{a}$ による固結 状況を示しており, 割裂脈の存在は全く認められず球形 状の固結体が得られていることがわかる。また，この場 合供試体の体積変化はごの薬液の場合でも装置上の最小 の計量単位である $50 \mathrm{cc}$ 以下であった。瞬結性薬液では, 後続薬液は先行薬液によるゲル化領域を突き破らざるを 得ないので注入圧は中昇するが, 固結形状と供試体の体 積変化がほとんど認められなかった点からみて, 事実上 割裂が生じなかったといえる。これは，砂の透水性が大 きくなるにつれて割裂圧が増加し割裂しにくい条件を有 していることに加えて, 試料 A のように透水性が特に大 きい砂では割裂圧が弾塑性体中の空洞を押し拡げるのに 必要な極限空洞内圧程度となり, 特定方向の割裂でなく 空洞周辺全体が破壊することが原因と考えられる9 .

写真一2 の試料 $\mathrm{E}$ の場合, 薬液のゲル化時間が長いほ ゼ固結形状が良好であったが, 試料 A ではゲル化時間が 長い薬夜ほど固結形状が悪くなった。特に, 割裂が最も 発生しにくい緩結性薬液 c では, 注入孔周りに球形状の 固結が得られず土槽の下部に厚さ $10 \mathrm{~cm}$ 程度にわたっ て固結した。これは, 試料 $\mathrm{A}$ は透水性が非常に大きいた

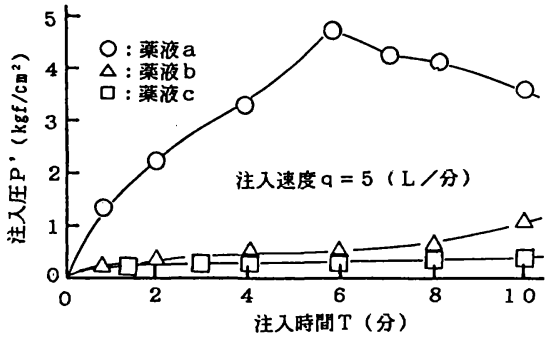

图一5 試料A の注入圧 $\boldsymbol{P}^{\prime}$ と注入時間 $\boldsymbol{T}$ の関係

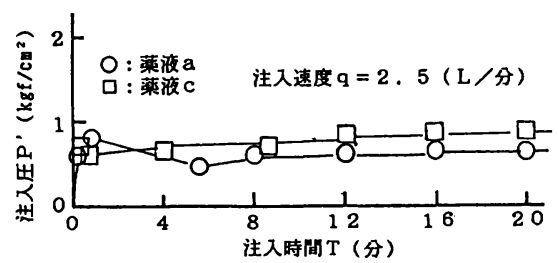

図一6 試料Hの注入圧 $\boldsymbol{P}^{\prime}$ と注入時間 $\boldsymbol{T}$ の関係

め間隙中の薬液がゲル化するまでの間に水との比重差で 沈降したためである.したがって，透水性が非常に大き い地盤ではゲル化時間が短いほど固結形状は良好になる と考えられる.

図一6には，透水性が試料 $\mathrm{E}$ より小さい試料 $\mathrm{H}$ の結果 を示している. 注入速度 $q=2.5$ ( $\mathrm{L} /$ 分), 全注入時間 $t=20$ (分間) である. この場合, 注入圧は薬液 $\mathrm{a}$ と薬 液 c でほとんど差がなく, 瞬結性薬液 a の場合でも注入 中における注入圧の増加は認められなかった．注入管周 りで薬液の浸透領域が形成されると，ゲル化によって浸 透部分の透水性が低下するため注入を続けると注入圧は 上昇しなければならないが注入圧の増加が認められない 事実より注入孔周りでは浸透領域がほとんど存在してい ないと考えられる. 注入圧が瞬結性と緩結性で一致して いることは，薬液がゲル化時間に無関係に同じ状況で注 入されていることになり，これが可能なのは薬液が常に 前方に割裂していく割裂注入状態以外考えられない，写 真一4 には，薬液 c の注入状況を示しているが，注入孔 周りの固結がほとんどなく, 薬液は数本の割裂脈に沿っ て供試体側方から外部へ流出していることがわかる.

注入圧に及ぼすゲル化時間の影響を明確にするため, 瞬結性薬液 a の注入圧とゲル化が生じない水による注入 圧の大きさを比較することにし，図一7にその結果を示 す。縦軸の $R_{a}$ は，水による注入圧 $P_{w}^{\prime}$ に対する瞬結性 薬液の注入圧 $P_{a}^{\prime}$ の割合である. $R_{a}$ は砂の透水性が大 きくなるにつれて増加しており， $R_{a}$ が大きいほど固結 形状はより球形状になる。したがって, 試験注入時にお ける水による注入圧と実際の注入圧の大きさを比較する ことが浸透注入か割裂注入かを推定する 1 つの簡易な方 


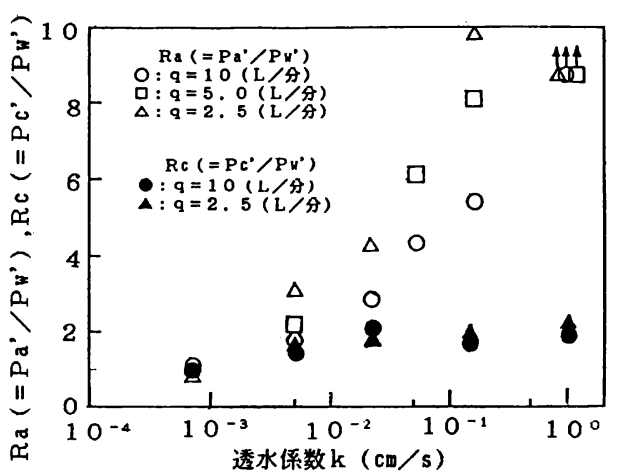

図一7 薬液 a, c の注入圧 $\boldsymbol{P}_{a}^{\prime}, \boldsymbol{P}_{c}^{\prime}$ と水の注入圧 $\boldsymbol{P}_{w}^{\prime}$

法と思われる．また，図中には，緩結性薬液 c の注入圧 $P_{c}^{\prime}$ と $P_{W}^{\prime}$ の比 $R_{c}$ も示しているが, この值は砂の透水 性によらず薬液と水の粘性比程度である。なお， $P_{a}^{\prime}$, $P_{c}^{\prime}$ は注入中の終值である.

以上の結果から，砂の透水性が小さくなるにつれて注 入圧に及ぼすゲル化時間の影響は小さくなり, 注入圧が 瞬結性と緩結性でほぼ一致するような場合には割裂注入 が主体となり注入管周りの固結はほとんど期待できない ことがわかった．また，瞬結性薬液の場合でも，砂の透 水性が大きいと割裂脈は発生せず良好な固結形状が期待 できることが明らかとなった。

\section{（2）注入圧に及ぼす注入速度, 経過時間, 砂の透水 性の影響}

ゲル化時間の長い薬液を注入する場合に注入形態が浸 透注入になるか, 割裂注入になるかを判断するうえでは, 注入圧 $P^{\prime}$ ～注入速度 $q$ 関係が基本となるので') ここ でも注入圧〜注入速度関係を調べた。

図一8には，薬液のかわりに水を用いた場合の $P^{\prime} \sim q$ 関係を示す. 図一 9 には, 実際の緩結性薬液 c を使用し た場合の結果を示す．この場合, 薬液の粘性が水より大 きいので, 注入圧が水の場合より若干大きくなるが全体 の傾向としては両者の差異が認められない. 文献 1）で は, 緩結性薬液の浸透注入条件は $q$ を増加したとき $P^{\prime}$ が増加する段階の注入速度であることを示した．そして 緩結性薬液が浸透注入になり得る最大の注入速度を限界 注入速度 $q_{C R}$ とすると $q_{C R}$ は, $P^{\prime} \sim q$ 関係において最大 の注入圧が得られる時点の注入速度であり, $q$ が $q_{C R}$ を 超えると割裂注入が主体となる.

写真一 5 には, 試料 $\mathrm{E}$ に対して薬液 $\mathrm{c}$ を $q=10$ ( $\mathrm{L} /$ 分) で注入した場合の浸透状況を示している. なお, 赤い着 色液は注入の最終段階で用いている．図一8の試料 $\mathrm{E} の$ $P^{\prime} \sim q$ 関係において $q=10$ (L/分) では浸透注入が可 能な段階であり, 赤い着色域が注入孔周りに同心円状に みられた結果と一致している. 写真一 6 には，透水性が

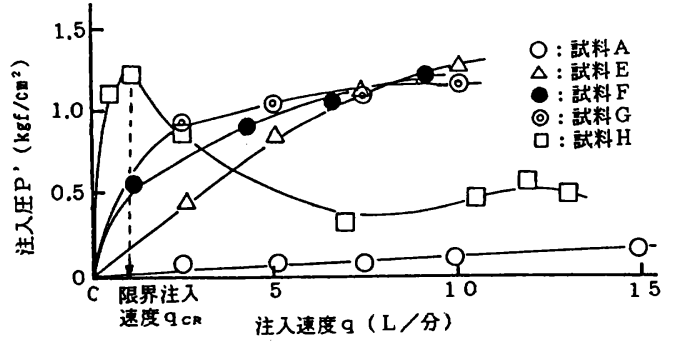

図一8 水の注入圧 $\boldsymbol{P}^{\prime}$ と注入速度 $\boldsymbol{q}$ の関係

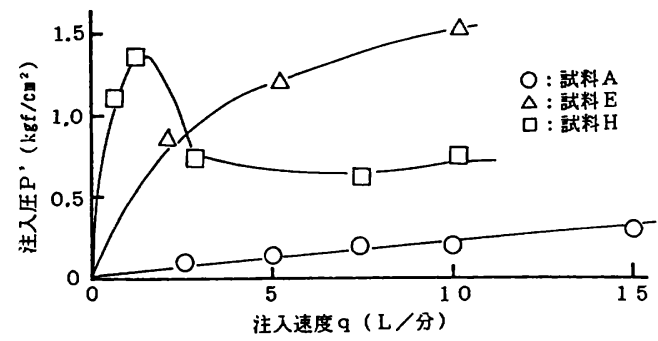

図一9 薬液 c の注入圧 $P^{\prime}$ と注入速度 $\boldsymbol{q}$ の関係

試料 $\mathrm{E}$ より小さい試料 $\mathrm{G}$ に薬液 $\mathrm{c}$ を $q=10$ ( $\mathrm{L} /$ 分) で 注入した場合の浸透状況を示す。この場合, 図一8の $P^{\prime} \sim q$ 関係において $q=10$ (L/分) では注入圧の減少 段階にはまだ達していない，固結形状は，写真一5に示 した試料 $\mathrm{E}$ の場合よりくずれるものの実質的には浸透注 入が可能なことを示している. 透水性がさらに小さい試 料 $\mathrm{H}$ で $q=2.5$ (L/分) の場合は, $P^{\prime} \sim q$ 関係において 注入圧の減少段階なので割裂注入を意味し, 薬液 c, 薬 液 $\mathrm{a}$ ともに固結領域がほとんよ゙存在しなかった図一6の 結果とも一致する. しかし, 試料Eに $q_{C R}$ 以下の注入速 度 10 (L/分)で注入した場合では瞬結性薬液 aにおいて, 緩結性薬液の場合と異なり鉛直厚板状の固結体（写真一 2参照）となったことより，緩結性薬液の浸透注入条件 を瞬結性薬液にそのまま適用することは困難となる。

図一10，図一11には，試料 $\mathrm{A}$, 試料 $\mathrm{E}$ の注入圧に及 ぼす注入速度の関係を示す。ただし，瞬結性薬液では図 一5に示したように注入過程においてピーク値に達した 後に減少する場合もあるので, ピーク値と終值の両者を

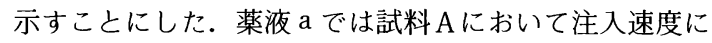
よらずすべて球形状の固結体が得られ，試料 $\mathrm{Eではごの}$ 注入速度でも鉛直厚板状の固結体が得られた．ゲル化時 間の長い緩結性薬液では, 注入圧 $P^{\prime}$ と注入速度 $q$ の関 係から注入形態を推定することができ, 注入速度が増す につれて注入圧 $P^{\prime}$ が増加する限り浸透注入が可能であ る. しかし, 瞬結性薬液の場合には, 緩結性薬液の場合 にみられるような注入形態と $P^{\prime} \sim q$ の関係は成立せず, 瞬結性薬液の $P^{\prime} \sim q$ から注入形態を推定することは困 


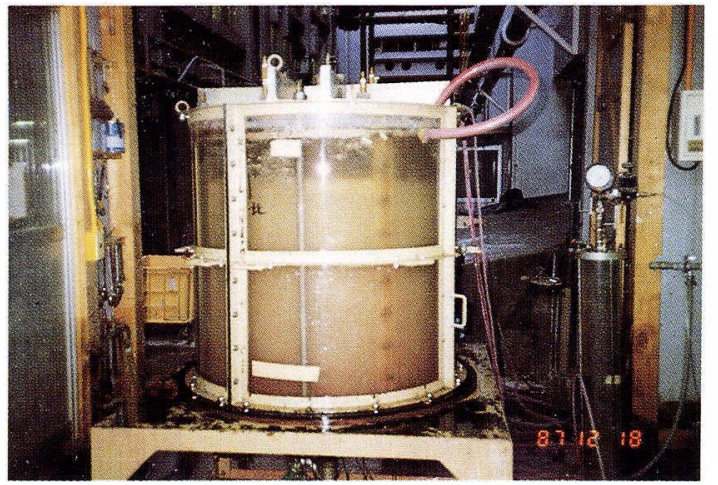

(a ) 装置の概要

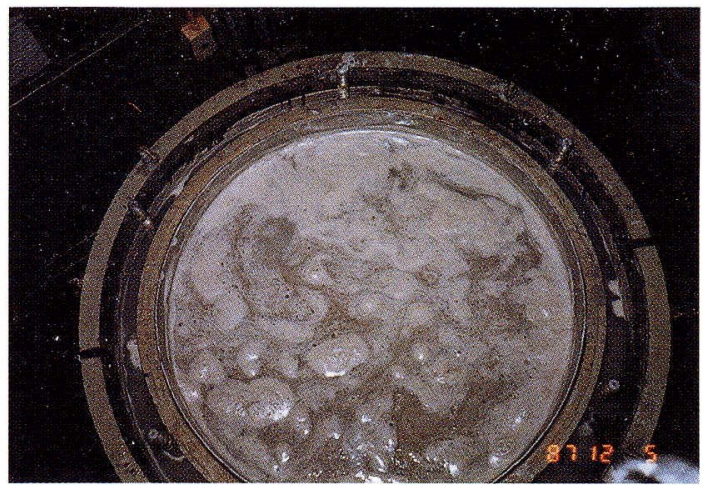

（b） アクリル外円筒上鋼製内円筒

写真一1 注入実験土槽

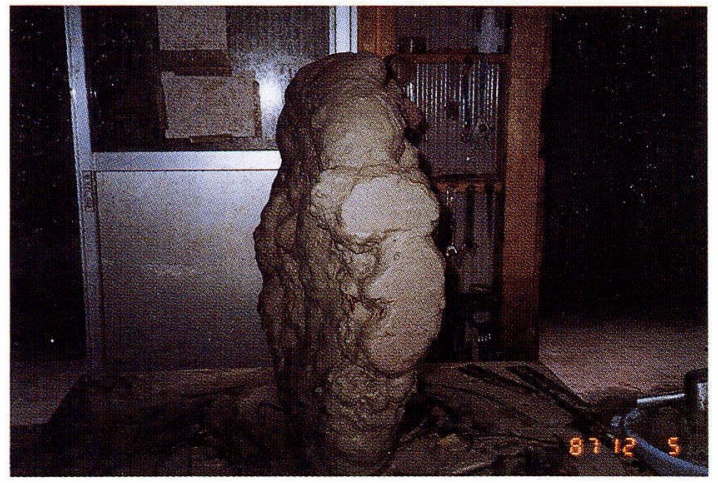

(a) 瞬結性薬液 a

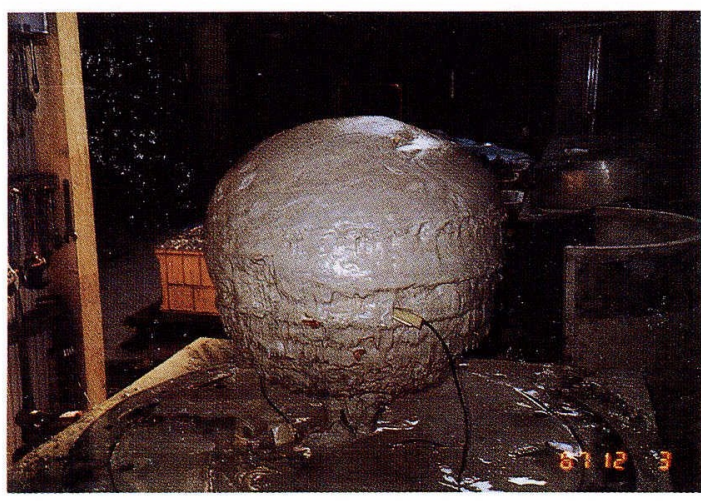

(c) 緩結性薬液 c

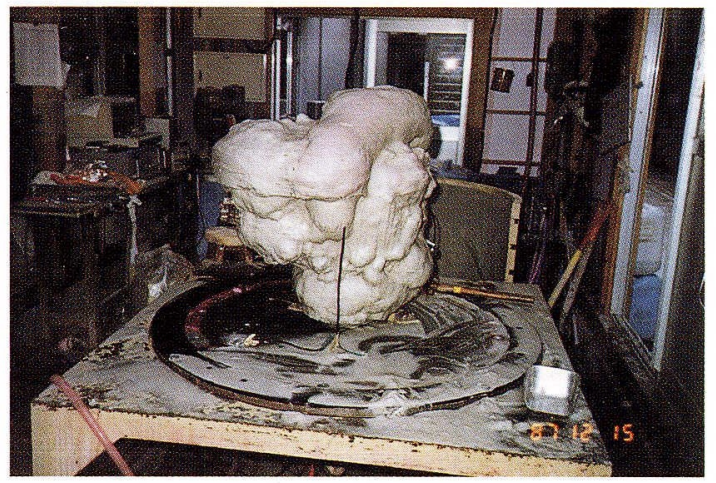

(b) 急結性薬液 b

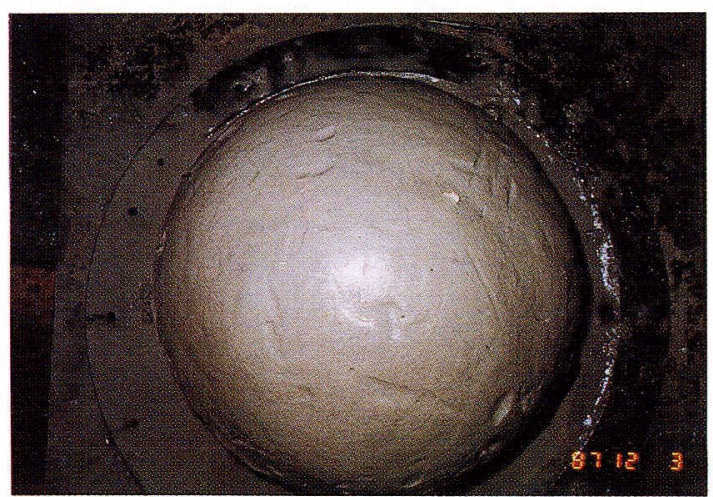

(d) 綏結性薬液 c (真上加ら)

写真一2 試料 $\mathrm{E}$ の注入固結形態 $(q=10$ ( $\mathrm{L} /$ 分), 全注入時間 $t=5$ (分)) 


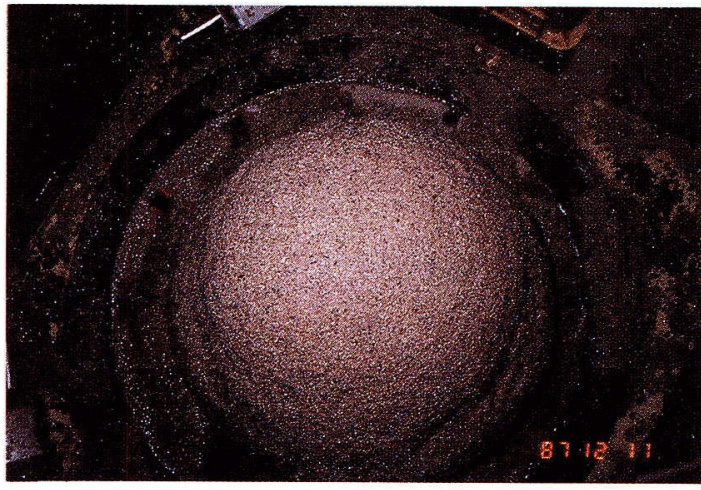

(a) 真上から

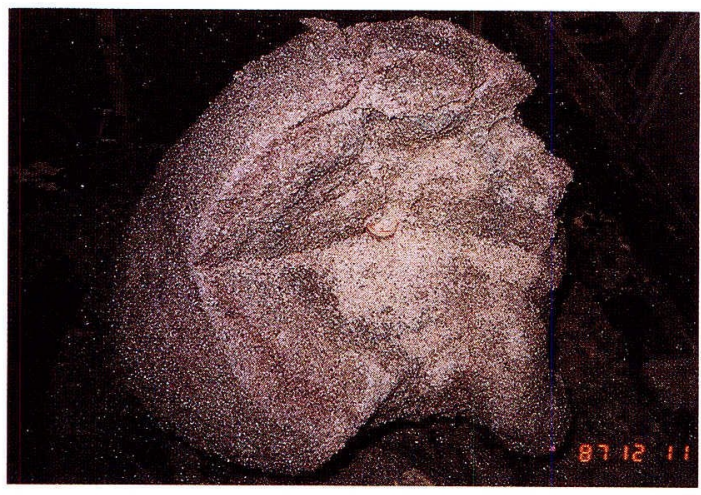

（b）浸透状況

写真一3 試料 A (ケイ砂 3 号) の瞬結性薬液 $\mathrm{a}$ による注入固結形態 $(q=10$ ( $\mathrm{L} /$ 分), $t=5$ (分))

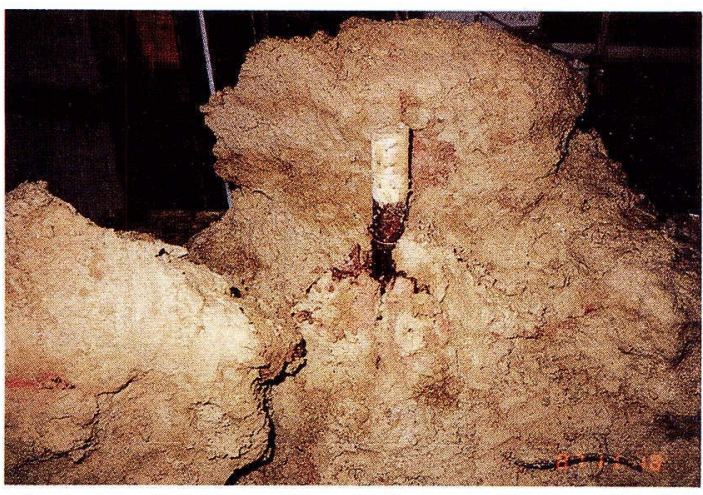

$q=10$ (L/分), $t=5$ (分)

(固結部分はほとんど存在しない)

写真一4 試料Hの緩結性薬液 Cによる注入形態

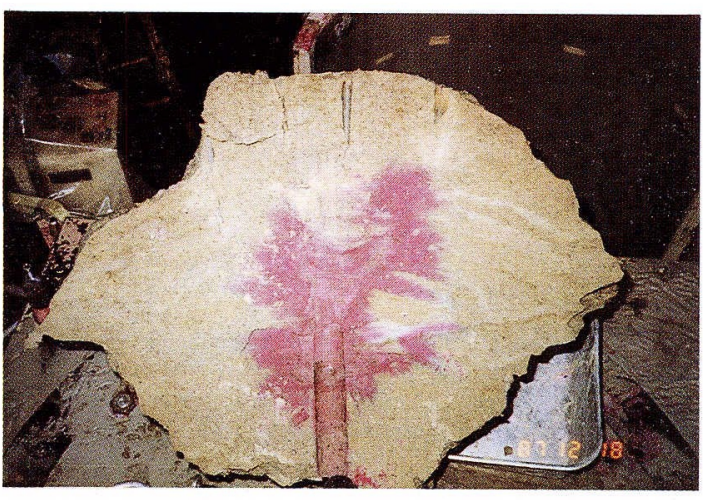

試料 $\mathrm{G}$ ( ケ 亿砂 7 号十木節粘士:)

$q=10$ (L/分), $t=5$ (分)

写真 6 緩結性薬液 $\mathrm{c}$ の浸透状況

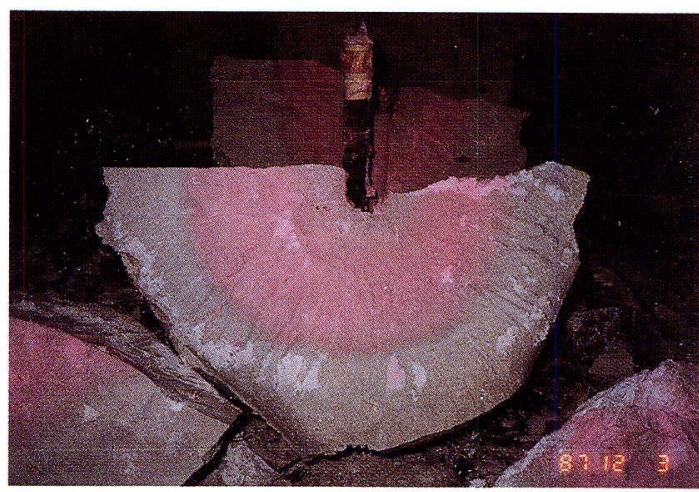

試料 $\mathrm{E}$ ( ケ 亿砂 7 号)

$q=10$ (L/分), $t=5$ (分)

写真一5 緩結性薬液 $\mathrm{C}$ の浸透状況

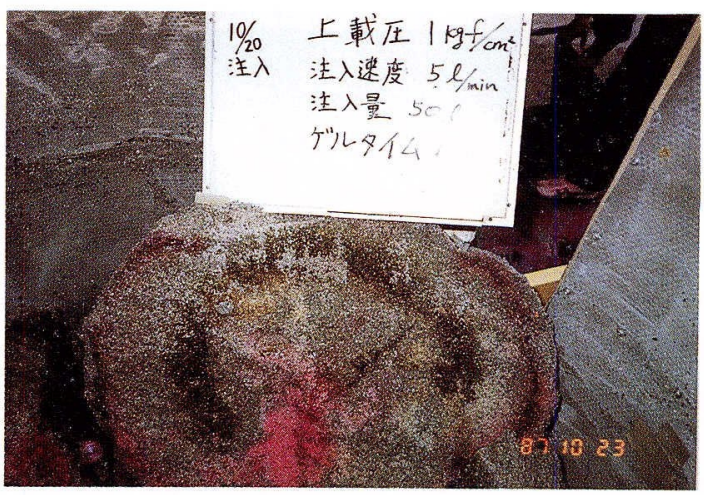

試料 A（ケ亿仯 3 号)

$q=5$ (L/分), $t=10$ (分)

写真一7 瞬結性薬液 a の浸透状況 


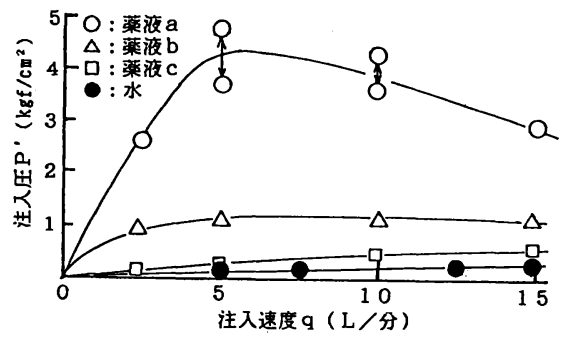

図一10 試料Aの注入圧 $\boldsymbol{P}^{\prime}$ と注入速度 $\boldsymbol{q}$ の関係

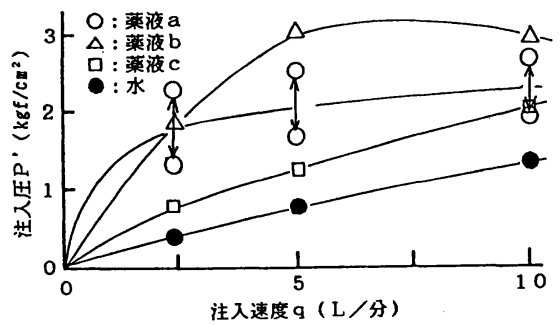

図一11 試料Eの注入圧 $\boldsymbol{P}^{\prime}$ と注入速度 $\boldsymbol{q}$ の関係

難となる．また，緩結性薬液の場合，注入速度 $q$ が小 さいほど浸透注入が得られやすいが，ゲル化時間の短い 急結・瞬結性薬液では， $q$ の減少は固結形状にとってむ しろマイナスとなる．これは， $q$ の低下は所定量を注入 するまでの注入時間を長くするため，ゲル化までに浸透 注入できる薬液量が減少するためである．事実，試料 $\mathrm{E}$ で $q=2.5$ (L/分) の固結形状は, $q$ が大きい場合に比 較してより偏平な板状となった。

図一12には，瞬結性薬液を用いた場合の試料 A, E, $\mathrm{H}$ の注入圧と注入時間の関係を示す. 注入速度 $q=2.5$ (L/分) である. 注入の初期では三者とも注入圧が増 加しているが，透水性が小さい試料ほど注入圧は速い段 階から減少傾向となっていることがわかる．図一13に は, 急結性薬液の結果を示している．試料 A, Eでは注 入圧は注入中増加しつづけているが，透水性が小さい試 料 $\mathrm{G}$ では注入圧は注入の終期において減少し始めてい る.したがって急結性薬液でも透水性が小さい試料では 注入圧が注入中に減少し始めることがわかる. 図一12, 13 において砂の透水性が大きいものほよ゙，注入圧はゲ ル化後も増加し続ける傾向にあり，この場合に限って瞬 結・急結性薬夜でも固結が良好であったことより, 注入 圧と注入時間の関係がゲル化時間の短い薬液の固結形状 を考えるうえで重要と思われる。

固結重量としては, だの薬液の場合でも注入速度 $q$ が緩結性薬液についての限界注入速度 $q_{C R}$ より小さい限 り $200 \mathrm{~kg}$ 前後となった.これは, 全注入量が間隙を $100 \%$ 填充すると仮定して求めた固結重量とほぼ同程度

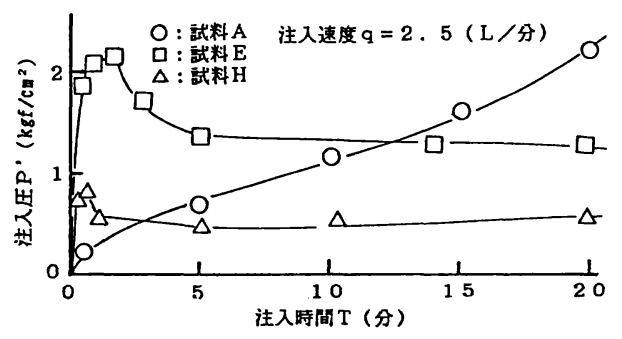

図一12 瞬結性薬液 a $の$ 注入圧 $\boldsymbol{P}^{\prime}$

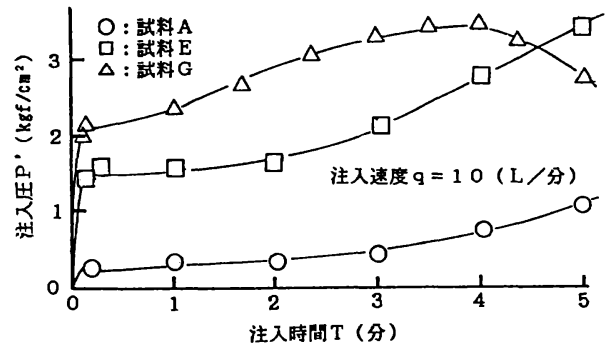

図一13 急結性薬液 b の注入圧 $P^{\prime}$

である. 瞬結性薬液 a では, 砂の透水性が小さいと $q$ が $q_{C R}$ 以下であっても写真一 2 に示したように鉛直厚板 状の固結亡なるが，この場合割裂は固結部に限られ未固 結部では浸透注入が得られているので薬液の口スは少な い. $q$ が $q_{C R}$ より大きいと末固結な砂自体の割裂が生じ るため, 薬液のロスが大きいことになる。 なお，ここで いう固結部分は, 注入後 1 日放置して試料に放水した際 に崩壊しない部分とした。

\section{4. 薬液の浸透メカニズム}

前章では，ゲル化時間の短い急結性・瞬結性薬液によ る注入圧と注入形態の関係について述べたが,ここでは これら薬液の浸透メカニズムについて述べる.

瞬結性薬液の注入に際しては, 注入時間よりもゲル化 時間の方が短いので，ゲル化した領域では継続注入され る薬液により割裂的現象が生ぜざるを得ない。しかし， 写真一3で示したように試料 Aでは割裂的注入は発生せ ず, 球形状の固結形状になっている.

試料 $\mathrm{A}$ は，透水性が大きく注入中にゲル化が始まった 固結領域内の個々の間隙が大きいため間隙中の小さい強 度のゲルは継続注入している薬液で穿孔されやすく, 固 結領域の透水係数はまだかなり大きい状態に維持されて いると思われる，透水性の大きい状態では割裂圧は大き く割裂は生じにくい9!。このためほぼ浸透注入のように 注入が進行でき, 固結形状が球状に成長し得る. しかし, ここでは先行薬液を後続薬液が次々と押し出していく本 来の浸透注入ではなく，すでにゲル化して移動できない 
間隙中の先行薬夜を後続薬液が穿孔して前方に進む状況 となり，固結領域の外周面から流出浸透して固結するこ とになる．したがって，後続の薬液ほぼ固結領域の外側 境界に近くなる．この状況は 2 種の着色薬液を時間差注 入した結果からも明確である，写真一7には，瞬結性薬 液を試料 Aに注入した場合の固結部断面を示している. 注入速度 $q=5$ (L/分), 全注入時間 $t=10$ (分間) で, 青い着色液は注入 2 分後加 1 分間，赤い着色液は注入 8 分後から 1 分間注入している. 赤い着色域は, 先に注 入した青い着色液の浸透領域の外側の固結部外周にほほ 同心円状に存在し，実質的には浸透注入であり割裂は生 じていないといえる. 透水係数の最も大きい試料 Aで注 入圧が一番大きいのは固結領域の間隙中のゲルを穿孔し ながら浸透的に注入が進行していくためであり，またこ のような注入圧でも割裂が発生しない条件をもっていた ことが原因である。

以上の結果より, 急結性, 瞬結性薬液の注入段階にお ける浸透メカニズムは次のように説明できる。ただし， 注入速度が 図一8で示した水で求めた限界注入速度 $q_{C R}$ 以上であれば，薬液のゲル化時間に関係なく注入の初期 から未固結な砂自体の割裂注入となるので，注入速度は どの薬液でも $q_{C R}$ 以下にすることが必要条件である。

a) 浸透注入段階薬液がゲル化する以前の浸透注 入段階で, 注入圧は経過時間に無関係な一定值をとる. 瞬結性薬液では, 注入直後から注入圧は増加し始めるの でこの段階はない．固結形態は球形状.

b）穿孔的浸透注入段階先行薬液のゲル化が始ま ると, 後続薬液は先行薬液による浸透固結部分を貫いて 前方に進行するが，しばらくは浸透固結部分の間隙ゲル を薬液が穿孔しながら球形状に浸透する状況が続く段階 となる．砂の透水性が大きいと間隙径が大きいので間腺 ゲルは穿孔されやすい，この段階では固結部の透水性が あまり低下しないので注入圧が大きくなっても割裂は発 生しにくい. また，ここでは浸透部分が拡大するにつれ 透水性の小さい領域が増大するので, 注入圧は時間とと もに増加の傾向を示す。

c) 割裂的注入段階 経過時間とともに注入圧が増 加し浸透固結部分の透水性も低下してくるので, 割裂が 生じやすくなり，さらに注入を続けると浸透固結領域に おいて割裂が発生する．割裂が発生すると固結領域を容 易に通過してその外側に薬液が浸透しやすくなるので, 一定の注入速度のもとでは注入圧が低下する．以後割裂 部から外側に浸透して固結領域が生長しここの領域が固 結すると次にはここで割裂が生じる。この状況が繰り返 されるので固結領域が割裂方向に厚板状に拡大され，固 結体の最小有効幅は注入を継続してもほとんど増大しな い.
以上のメカニズムをふまえて瞬結性薬液を試料 $\mathrm{E} に$ 注 入した場合を考えると注入のごく初期では図一12のよ うに注入圧の増加が生じているので試料 A のように穿孔 的浸透注入により球状に固結体が成長していると考えら れる. しかし, 球状固結体が少し大きくなると試料Eで は試料 $\mathrm{A}$ と異なり，個々の間隙が小さいので間隙中のゲ ルを後続の薬液が穿孔して通過するために要する圧力が 大きくなり割裂が発生する。この場合，鉛直圧 (上載圧) よりも水平压の方が小さいので割裂面は鉛直方向に通常 は一平面生じる，割裂面が少ないので割裂脈幅が太くな り, 脈中を通る液圧は注入圧に近い。薬液は固結領域内 の割裂面を通り固結体の外側に浸透的に入っていく。こ のときの浸透形状は写真一2(a) のように鉛直でほぼリ ング状になる.この浸透部分はすぐに固結していくので, ある程度の大きさになると注入圧が上がり再び割裂が発 生する。このような浸透と割裂が繰り返され，割裂方向 は常にはじめの割裂方向をとるので固結体の形状は鉛直 な板状のものとなる．注入圧は初めの間は増加してピー クに達し，最初の割裂が発生する．以後浸透と割裂が繰 り返されるので，この場合の注入圧は次々に形成される 固結部分の割裂圧で決まる.

試料 $\mathrm{H}$ では透水係数が小さいので注入速度 $q=2.5$ (L/分）では水を用いても割裂する。したがって, 瞬 結性薬液では当然はじめから割裂が発生しており, 割裂 脈からの浸透もごくわずかである．このために固結体は ほとんどなく脈状のホモゲルが数本みられるのみであ る．注入圧は固結の影響を受けない試料 $\mathrm{H}$ 自身の割裂圧

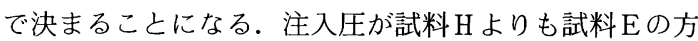
が大きいのは割裂圧の差のためである.

急結性薬液の注入における固結形状は透水係数の著し く大きい試料 $\mathrm{A}$ を除き瞬結性のものよりもかなり球形状 に近くなり，割裂脈もほとん亡゙みられなかった．急結性 薬液は薬液がゲル化するまでの時間が瞬結性薬液よりか なり長いので，砂自体の割裂が生じない場合には浸透注 入となる時間が長くなる．また薬液が間隙中でゲル化し 始めても初期においては瞬結性薬液のゲルよりも強度が 弱いので後続薬液で穿孔されやすいと考えられる．この ため固結形態は瞬結性薬液よりも球形状に近づく.

\section{5. 実質浸透注入の条件と限界}

ゲル化時間の長い緩結性薬液の注入において, 実質浸 透注入とするための注入条件"にについてはすでに明らか にしたので，ゲル化時間の短い瞬結・急結性薬液の場合 における注入条件を考えることにする.

図一8 の注入速度と注入圧の関係において, 注入速度 が限界注入速度 $q_{C R}$ をこえると末固結部の砂自体の割裂 が生じるために薬液のゲル化時間にかかわらず実質浸透 


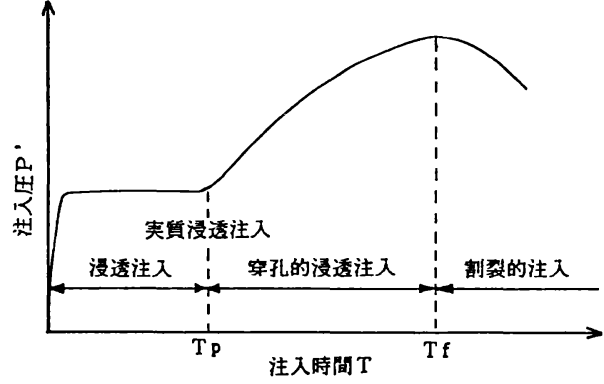

図一14 砂質地盤におけるゲル化時間の短い薬液の注入圧と注 入時間の一般的関係

(注入速度が限界注入速度 $q_{C R}$ 以下の場合)

注入は望めない，注入速度 $q$ が $q_{C R}$ より小さい場合に, ゲル化時間の短い急結・瞬結性薬液を注入した場合の注 入圧・注入時間の一般的な関係は図一14のようになる.

$T_{p}$ をこえるとゲル化が始まり, 注入圧が増加しはじ めるが，瞬結性薬液では図中の $T_{\rho}$ はほとんど存在しな い. $P^{\prime} \sim T$ 関係における最大注入圧が得られる注入時 間 $T_{f}$ の值は, 砂の透水性, ゲル化時間の影響を受け, 透水性が大きくゲル化時間が長いほど $T_{f}$ は大きくな る. 砂の透水性が大きいほど, 粒子間隙も大きく間隙中 のゲルが穿孔されやすいので長期間にわたってこの穿孔 段階が続くことになる．注入形態として考えると $T_{p}$ か ら $T_{\boldsymbol{f}}$ までの間は, 前章で述べた穿孔的な注入段階に相 当する. $T_{f}$ に達するとそれまでの固結領域が割裂する ので注入圧は下がり, 以降浸透と割裂が繰り返され固結 形態は板状になる。

このため実質浸透注入とするためには，T $T_{f}$ までにで きるだけ大量の薬液を注入することが望ましく，注入速 度を低下させることはむしろ有効固結径を小さくするこ とになる．注入速度の低下は，所定の注入量を注入する 時間を長くすることになり，相対的にゲル化時間を短く することに相当するためである．したがって，注入速度 は固結領域外の砂を割裂しない最大の注入速度である $q_{C R}$ を用いることが最も効果的である，ただし，特に透 水性が大きい試料 A では $q_{C R}$ が非常に大きいので， $q_{C R}$ より小さい実用の注入速度を用いても十分に浸透注入さ せることができる．瞬結性よりゲル化時間の長い急結性 薬液では $T_{f}$ の值が大きくなるので同じ注入速度でも浸 透範囲を大幅に広げることができる.

以上は注入のあり方であるが，次に実質浸透注入の可 能限界について考える．浸透注入の限界は注入速度や深 度により異なるが，ここでは一応経済的な注入速度と考 えられる 10 (L/分) で全量 $50(\mathrm{~L})$ 注入するときの実 質浸透可能限界について調べることにした。また，深度 については $10 \mathrm{~m}$ 前後を対象とする場合が多いので, 上

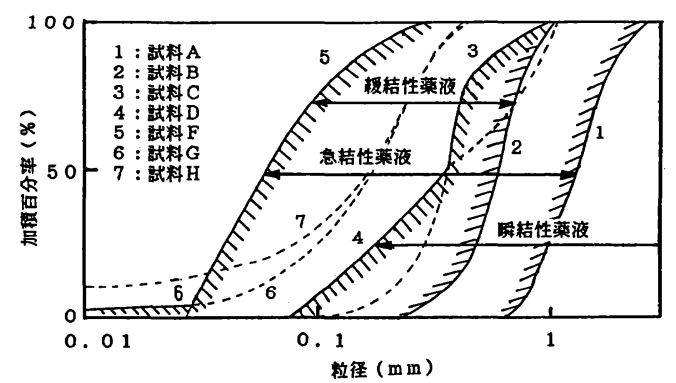

図一15＼cjkstart粒度分布と実質浸透注入限界

表一3 透水係数と実質浸透注入限界

\begin{tabular}{|c|c|c|c|}
\hline 薬液の種類 & $10^{-4}$ & 透水係数 $\mathrm{k}(\mathrm{cm} / \mathrm{s})$ & $10^{\circ}$ \\
\hline 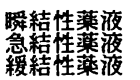 & & $\longmapsto$ & \\
\hline
\end{tabular}

載圧は $1.0\left(\mathrm{kgf} / \mathrm{cm}^{2}\right)$ とした。

図一15には，粒径加積曲線による実質浸透注入の可 能限界を示す。粒径加積曲線における左側限界線の広が りは，瞬結性が最も小さくなり緩結性楽液 c と急結性薬 液 b は同じであった。ただし，限界線に近くなると固結 形状としては薬液 c の方がより球形状ですぐれている. また，この左側限界線（5-6）は，瞬結性薬液 a で鉛直 厚板状の固結体が得られる限界でもある。このとき，ど の薬液も曲線 5 および曲線 6 では, 一応注入可能である のに対して，細粒分を含む破線 7 では，注入不可能であ ることから注入限界には粘土分, シルト分という細粒分 が大きく影響していることがわかる，これは，細粒分が 地盤の透水性を低下させるのに大きく影響するためであ る。なお，左側限界線として曲線 5 から曲線 6 へつなが る曲線を用いているが，これは曲線 5 と曲線 6 で注入可 能であったことによるものである，一方，右側限界線の 広がりもゲル化時間によって大きく異なる。これは，透 水性が大きいとゲル化時間が長い薬液では, 薬液自体の 沈降現象が生じてマイナスになるからである.

また，実質浸透限界を透水係数 $k$ で表わせば，表一3 のようになる。

なお，以上の実質浸透限界は， $q=10$ (L/分)， $\sigma_{v}=$ $1.0\left(\mathrm{kgf} / \mathrm{cm}^{2}\right)$ の場合であり, $\sigma_{V}$ が $1.0\left(\mathrm{kgf} / \mathrm{cm}^{2}\right)$ よ り大きいと割裂しにくくなるので，左側限界線はどの薬 液もより左にずれ，適用地盤が広がると考えられる。

\section{6. ま と め}

本研究は, 砂質地盤におけるゲル化時間の短い瞬結 ・ 急結性薬液の浸透メカニズムや注入形態について調査し たものであり，主な結果は以下のとおりである。 
（1）瞬結性および急結性薬液でも注入速度 $q$ が緩 結性楽液についての限界注入速度 $q_{C R}$ をこえると, 地盤 が割裂し薬液の固結効果が大きく低減する，注入速度が 限界注入速度以下の場合, 急結, 瞬結性薬液による注入 圧 $P^{\prime}$ と注入時間 $q$ の関係は, 図一14 に示した $3 つ の$ 段階に分けて考えることができ, 注入時間とともに注入 圧が増加している段階では間隙ゲルを後続薬液が穿孔す る状況下での実質浸透注入が可能である.この穿孔的浸 透注入の段階は, 砂の透水性が大きいほど長期間継続さ れることになるので, 瞬結性薬液であっても砂の透水性 がかなり大きい場合には球形状の固結体が得られる. 注 入圧がピーク值を過ぎて低下する段階では, 割裂注入に なり固結形状が板状に形成するので注入効果は小さくな る.

（2）浸透注入可能限界は, 図-15 および表一3に示 したようになり, 砂質地盤の透水性が大きいものほどゲ ル化時間の短い薬液の使用が適している. 透水性がかな り大きな地盤で緩結性薬液を使用すると, 薬液と地下水 との比重差で薬液が沈降して所定の領域で薬液が固結し ないことに注意すべきである．透水性が小さい場合にゲ ル化時間の短い薬液を使用する場合には, 限界注入速度 に近い大きな注入速度を用いて短時間にできるだけ多く の薬液を浸透させることが望ましい.

この研究では注入状態を考えるうえで基本となる均一 地盤を対象としたが, 実際の注入現場では不均一な場合 が少なくなく, 不均一地盤における薬液の挙動を調査し 注入のあり方を解明することが残された今後の課題であ
る.

最後に本研究にあたっては, 東京電力（株）の援助を 受けたことを記し，謝意を表します。また，注入実験の 実施については, 卒業論文として研究に参加した佐藤洋 一氏, 末弘 保氏, 福井義弘氏, 森 拓雄氏によるとこ ろが多く，感謝する次第です.

1）森麟・田村昌仁・平野 学：ゲル化時間の長い薬液 の砂質地盤における注入形態とその支配条件, 土木学会 論文集, No. 388, pp. 131 140, 1987.

2) Karol, R. H. : Chemical grouting, Dekker, p. 162, 1983.

3）柴崎光弘 -下田一雄 : 最新の薬液注入工法の設計と施工, pp. 83 92, 1985.

4）三木五三郎・佐藤剛司ほか：瞬結性薬液の地盤注入機構 に関するモールド実験, 第 14 回土質工学研究発表会, p. $1589,1979$.

5）千田昌平・苗村正三・武田節朗：大型加圧モールドにお ける薬液注入実験, 第 14 回土質工学研究発表会, p. 1593, 1979.

6）島田俊介：最新の地盤注入工法, 理工図書, p. 109, 1982.

7）所 武彦：最近のシールド工事における地盤改良工法の 実例, 日本プロジェクトリサーチ, NS-7, 13, 1987.

8）薬液注入工法の調査・設計から施工まで, 土質工学会編, pp. $161 \sim 163,1985$.

9）森麟・田村昌仁・千 柄植：砂質地盤における割裂 発生機構, 土木学会論文集, No. 388, pp. 61 70, 1987.

10) Vesic, A.S. : Expansion of cavities in infinite soil mass, Proc. ASCE, SM3, pp. 265 290, 1972.

(1988.8.13・受付) 